\title{
Kecernaan dan Fermentabilitas Tandan Kosong Sawit yang di Fermentasi dengan Mikroba Tanah secara in-vitro
}

\author{
Mardiati Zain \\ Jurusan Nutrisi dan Makanan Ternak Fakultas Peternakan \\ Universitas Andalas, Kampus Limau Manis Padang
}

\begin{abstract}
The objective of this research was to determine the effect of fermentation by soil microbes on the in vitro $D M, N D F, A D F$ digestibility and fermentability characteristics of palm empty bunch. Palm empty bunch is fermented by $10 \%$ soil microbes inoculum / $\mathrm{kg} \mathrm{DM}$ with length of $0.1,2$ and 3 weeks fermentation at aerobic condition. Digestibility was determined after $48 \mathrm{~h}$ incubation with rumen fluid of Tilley and Terry technique. Data were analyzed as a Block randomized Design. Digestibility of DM, NDF and ADF, were difference among treatments. In vitro DM digestibility after $48 \mathrm{~h}$ was higher for 2 weeks of fermentation (50,36\%) than for 0,1 , and 3 wk fermentation $(33,72,48,09$, and $46,36 \%)(P<0,05)$. Neutral Detergen Fiber digestibility after $48 h$ was higher for 2 weeks of fermentation (39,5\%) than for 0,1 , and 3 wk fermentation $(28,8,34,82$, and $30,56 \%)(P<0,05)$. In vitro ADF digestibility after $48 \mathrm{~h}$ was also higher for 2 weeks of fermentation (34.88\%) than for 0, 1, and 3 wk fermentation $(20,9,29,73$, and 26.) $(P<$ 0.05 ). The average of $\mathrm{pH}$ was non difference among treatment. Concentration of $\mathrm{NH} 3$ was increase for all treatment, and concentration of VFA was also higher for 2 weeks fermentation $(113,46 \mathrm{mM})$. It was concluded that palm empty bunch fermented by soil microbes for length of 2 weeks fermentation has better digestibility and fermentability.
\end{abstract}

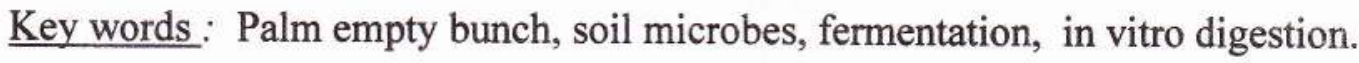

\section{Pendahuluan}

Penganekaragaman

sumber pakan serat pada ternak ruminansia perlu dipikirkan, karena ketersediaan rumput terasa semakin sulit terutama didaerah padat penduduk. Sumber pakan serat alternatif yang mempunyai potensi cukup besar adalah tandan kosong sawit (TKKS) yang merupakan limbah pengolahan kelapa sawit yang jumlahnya cukup besar setiap tahun seiring dengan meningkatnya luas perkebunan sawit di Indonesia. Tandan kosong sawit ini tergolong pakan serat yang bermutu rendah dengan kandungan lignin yang tinggi $(14 \%)$ dan protein, kecernaan serta palatabilitasnya rendah. Umumnya kecernaan pakan serat ini hanya berkisar $30-40 \%$. Penggunaan pakan ini dalam ransum ternak ruminansia hanya bisa menggantikan $25 \%$ rumput (Mardiati, Zain, et al, 2000; 2001).

Selulosa, hemiselulosa dan lignin adalah fraksi utama dari dinding sel tanaman yang tergolong pada senyawa polisakarida. Dalam prakteknya sangat sulit untuk menggunakan selulosa dan hemiselulosa ini secara efektif untuk pakan ternak karena lignin yang berada disekitar polimer selulosa dan hemiselulosa menghambat pencernaan mikroba rumen. Beberapa peneliti telah melakukan delignifikasi secara fisik, kimia dan biologis yang dapat meningkatkan kemudahan selulosa dan hemiselulosa dihidrolisis secara 
enzimatis (Sadder et al., 1982 Lin and Ladisch, 1985).

Untuk mengoptimalkan penggunaan tandan kosong sawit dalam ransum memerlukan sentuhan teknologi. Untuk itu perlu dilakukan suatu proses pengolahan yang mampu memutus ikatan lignin dengan selulosa maupun hemiselulosa sehingga kecernaannya bisa meningkat. Usaha untuk meningkatkan kecernaan atau fermentabilitas pakan serat ini dapat dilakukan dengan memberikan perlakuan biologi (fermentasi dengan mikroba).

Prinsip dasar pengolahan biologis pada pakan serat hampir sama dengan perlakuan kimia yaitu merusak ikatan lignoselulosa secara enzimatis, namun pengolahan ini memiliki kelebihan dengan adanya aktivitas mikroba yang memungkinkan biodegradasi lignin dengan merusak gugus aromatik dari lignin (Ibrahim and Pearce, 1980). Berbagai pengolahan biologis yang umum dilakukan antara lain pengomposan, pembuatan silase, pertumbuhan jamur dan penambahan enzim yang bertujuan untuk mengubah struktur fisik bahan makanan melalui delignifikasi atau penghancuran lignin oleh mikroorganisme dan meningkatkan protein bahan makanan dengan protein mikroba (Yunus, 1991). Berbagai jenis mikroba terutama kapang telah banyak digunakan dalam proses fermentasi.

Mikroba tanah terdiri dari banyak jenis dan yang mempunyai kemampuan untuk mendekomposisi pakan serat ini adalah tergolong kedalam kapang (fungi). Pada aerasi tanah yang baik fungi merupakan kelompok mikroorganisme tanah terbesar (Alexander, 1977) dan biasanya berada pada permukaan atau lapisan tanah atas yaitu sampai pada kedalaman $30 \mathrm{~cm}$ dari permukaan tanah (Landecker, 1972). Fungsi dari tanah ini merupakan spesies yang memiliki kemampuan hidup dan daya saing paling tinggi dibanding mikroorganisme yang lainnya. $\mathrm{Hal}$ ini disebabkan oleh : pertumbuhannya yang relatif cepat, efisiensi metabolik yang tinggi dalam menghasilkan enzim dan kegunaannya pada substrat, mempunyai kemampuan memproduksi senyawa tertentu (seperti antibiotik) yang bersifat toksik bagi mikroba lain dan dan memiliki toleransi yang tinggi terhadap antibiotik (Landecker, 1972). Dharmaputra et al. (1989) menyatakan bahwa cendawan tanah mempunyai peranan yang paling besar dalam proses dekomposisi selulosa, lignin dan kitin. Untuk itu penggunaan mikroba asal tanah dalam fermentasi tandan kosong sawit diharapkan mampu mendegradasi polimer komplek menjadi bentuk yang lebih sederhana sehingga mudah dicerna oleh ternak.

\section{Materi Dan Metode}

Tandan kosong sawit yang akan digunakan dipotong - potong atau dicincang kira - kira sepanjang 5-10 $\mathrm{cm}$ kemudian dijemur dibawah sinar matahari sampai kering udara. Kemudian bahan tersebut disterilisasi selama 15 menit.

\section{Preparasi Inokulan}

Tanah yang akan digunakan sebagai sumber mikroba diambil pada kedalaman 2-4 cm dari permukaan tanah ditimbang dan dilarutkan dalam larutan steril dengan perbandingan 1 : 10. Larutan steril terbut dari $2 \mathrm{~g}$ $\mathrm{NaNO}_{3}, 0,1 \mathrm{~g} \mathrm{H}_{2} \mathrm{HPO}_{4}, 0,5 \mathrm{~g} \mathrm{KCl}$, $0,5 \mathrm{~g} \mathrm{MgSO}_{4}, 7 \mathrm{H}_{2} \mathrm{O}$ dan $6,5 \mathrm{~g}$ yeast extract yang dilarutkan dalam aquades 
sehingga volume menjadi 1 liter (Parkinson et al., 1971) dan disterilisasi dalam autoclave pada suhu $120^{\circ} \mathrm{C}$ selama 15 menit. Campuran tanah dengan larutan steril kemudian di blender sampai terbentuk suspensi halus (10 menit) dan disaring dengan kasa steril untuk diambil fitratnya. Filtrat yang diperoleh ditambahkan dengan antibiotik sebanyak 30 mikrogram per liter.

Tandan kosong sawit yang telah steril dimasukkan dalam kantong plastik dan ditambah air sehingga kadar air bahan mencapai $60 \%$ dan kemudian disemprot (diciprati) dengan filtrat tanah sebanyak $10 \%$ dari berat substrat. Kantong plastik diikat tetapi didalamnya tetap ada ruang udara dan dibiarkan pada suhu kamar selama 0 , 1,2 dan 3 minggu sesuai perlakuan.

Pada akhir fermentasi kantong plastik dibuka dan diamati warna, bau, pertumbuhan kapang dan pengukuran $\mathrm{pH}$. Untuk uji kualitas nutrisi bahan yang sudah difermentasi diaduk dan dikeringkan dalam oven $60^{\circ} \mathrm{C}$ selama 48 jam dan digiling dan selanjutnya dianalisis

Analisis Kualitas Nutrisi
Sampel bahan tandan kosong sawit hasil fermentasi yang telah digiling akan dianalisis kandungan fraksi seratnya (Van Soest). Evaluasi kecernaan dilakukan dengan fermentasi secara in vitro dalam water shaker bath (Tilley and Terry, 1969).

Percobaan dilakukan dengan menggunakan Rancangan Acak Kelompok (RAK) 4 x 4 dimana terdapat 4 perlakuan (lama penyimpanan $0,1,2$, dan 3 minggu) dengan 4 kali ulangan. Pengaruh perlakuan terhadap peubah yang diukur dianalisis dengan Anova. (Steel and Torrie, 1980).

\section{Hasil Dan Pembahasan}

Komposisi Fraksi Serat Tandan Kosong Kelapa Sawit Fermentasi

Fermentasi secara anaerob terhadap tandan kosong kelapa sawit (TKKS) selama $0,1,2$, dan 3 minggu menyebabkan terjadinya perubahan komposisi kimia (fraksi serat) dari TKKS tersebut seperti terlihat pada Tabel 1.

Tabel 1. Pengaruh Fermentasi dengan Mikroba Tanah terhadap Komposisi Kimia TKKS

\begin{tabular}{lcccc}
\hline \multirow{2}{*}{ Zat makanan } & \multicolumn{4}{c}{ Perlakuan } \\
\cline { 2 - 5 } & $\mathrm{A}$ & $\mathrm{B}$ & $\mathrm{C}$ & $\mathrm{D}$ \\
\hline NDF & 77,82 & 75,28 & 72,73 & 71,64 \\
ADF & 52,77 & 51,29 & 49,63 & 52,28 \\
Selulosa & 35,77 & 35,87 & 34,06 & 36,18 \\
Hemiselulosa & 25,05 & 23,99 & 23,10 & 19,36 \\
Lignin & 14,16 & 14,62 & 14,62 & 15 \\
Silika & 0,84 & 0,8 & 0,95 & 1,10
\end{tabular}

Keterangan: $\quad \mathrm{A}=$ TKKS tanpa fermentasi

$\mathrm{B}=$ TKKS yang difermentasi selama 1 minggu

$\mathrm{C}=$ TKKS yang difermentasi selama 2 minggu

$\mathrm{D}=$. TKKS yang difermentasi selama 3 minggu 
Dari tabel diatas terlihat bahwa mikroba tanah mampu mendekomposisi fraksi serat dari TKKS yang terlihat dengan menurunnya kandungan fraksi serat seperti NDF, ADF, selulosa dan hemiselulosa dari TKKS. Juga terlihat bahwa semakin lama waktu fermentasi kandungan fraksi serat semakin turun. Hal ini disebabkan pada awal fermentasi (0-1 minggu) kapang menggunakan komponen bahan organik mudah larut sebagai substrat untuk aktivitas dan kelangsungan hidupnya, sedangkan komponen yang sulit dicerna (serat kasar) belum digunakan sehingga kadarnya lebih tinggi. Pada waktu fermentasi yang lebih lama $(2-3)$ minggu kadar serat kasar tersebut terus menurun karena mikroorganisme tanah (kapang) mulai menggunakan komponen serat kasar dari TKKS sebagai sumber energi. Penurunan fraksi serat dengan bertambah lamanya waktu fermentasi juga menunjukkan bahwa aktivitas pertumbuhan dari kapang mampu menembus dinding sel tanaman.

Tapi berbeda dengan kandungan lignin dimana semakin lama waktu fermentasi lignin cenderung meningkat. Hal ini sesuai dengan pendapat pendapat Waksman (1952) bahwa suatu bahan seperti jerami dibenamkan dalam tanah akan mengalami penurunan persentase selulosa dan hemiselulosa, sedangkan protein kasar dan lignin meningkat. Peningkatan protein kasar disebabkan oleh adanya tambahan nitrogen dari mikroorganisme tanah, sedangkan meningkatnya lignin disebabkan oleh menurunnya jumlah selulosa, hemiselulosa dan karbohidrat yang mudah larut lainnya, tetapi secara kuantitatif banyaknya lignin itu sendiri tetap.

\section{Kecernaan TKKS Fermentasi}

Kualitas suatu bahan pakan tidak bisa hanya ditunjukkan dari hasil analisa kimia bahan itu saja, karena kesanggupan ternak berbeda dalam memanfaatkan suatu pakan. Pengujian daya cerna perlu dilakukan untuk mengetahui manfaat suatu bahan pakan bagi ternak.

Pengaruh fermentasi TKKS dengan mikroba tanah dengan waktu yang berbeda terhadap kecernaan zatzat makanan dapat dilihat pada Tabel 2.

Hasil analisis ragam memperlihatkan bahwa kecernaan zat - zat makanan TKKS fermentasi terlihat meningkat dengan meningkatnya lama waktu pemeraman. Kecernaan masing - masing perlakuan memperlihatkan perbedaan yang sangat nyata $(\mathrm{P}<$ 0.01). Hasil uji DMRT memperlihatkan bahwa kecernaan secara umum tertinggi pada TKKS yang difermentasi selama 2 minggu (perlakuan C).

Tingginya kecernaan pada perlakuan $\mathrm{C}$ disebabkan fraksi serat dari TKKS pada perlakuan tersebut cukup rendah dibanding perlakuan $\mathrm{A}$ dan B. Ini membuktikan bahwa fermentasi TKKS dengan mikroba tanah selama 3 minggu mampu meningkatkan kualitas dari TKKS tersebut sehingga menjadi lebih fermentabel dalam rumen dan menghasilkan kecernaan yang lebih baik.

Rendahnya kecernaan zat-zat makanan pada perlakuan $\mathrm{D}$, walaupun kandungan fraksi seratnya lebih rendah dibanding perlakuan $\mathrm{A}, \mathrm{B}$ dan $\mathrm{C}$, lebih disebabkan oleh tingginya kandungan lignin dari TKKS pada perlakuan D tersebut. Hal ini sesuai dengan pendapat Sutardi (1980) yang menyatakan bahwa bila kandungan ADL/lignin suatu bahan makanan 
tinggi maka kecernaan bahan makanan tersebut akan rendah.

Dari Tabel 2 terlihat bahwa perlakuan yang terbaik adalah TKKS yang difermentasi dengan mikroba tanah selama 2 minggu. Pada fermentasi 3 minggu kecernaan tetap meningkat dibanding dengan TKKS tanpa fermentasi namun lebih rendah dibanding fermentasi 2 minggu dan 1 minggu.

\section{Karakteristik Cairan Rumen in vitro}

Parameter metabolisme rumen seperti $\mathrm{pH}$, kadar $\mathrm{NH} 3$ dan VFA cairan rumen juga menunjukkan tingkat fermentabilitas suatu bahan pakan dalam rumen. Rataan nilai $\mathrm{pH}$, kadar NH3 dan VFA cairan rumen dari TKKS percobaan dapat dilihat pada Tabel 3.

Hasil analisis ragam memperlihatkan bahwa $\mathrm{pH}$, produksi $\mathrm{NH} 3$ dan produksi VFA pada masing-masing TKKS memberikan pengaruh yang berbeda tidak nyata $(\mathrm{P}>0,05) . \mathrm{pH}$ cairan rumen pada penelitian ini berkisar antara 6,8 - 7,19 dan telah memenuhi syarat untuk menjamin aktifitas mikroba rumen yang optimal, dimana $\mathrm{pH}$ rumen yang normal untuk aktifitas mikroba selulolitik adalah 6,0 $-7,0$ (Church, 1979).

Tabel 2. Rataan Kecernaan Zat-zat Makanan TKKS Fermentasi (\%)

\begin{tabular}{lcccc}
\hline \multirow{2}{*}{ Parameter } & \multicolumn{5}{c}{ Kecernaan } \\
\cline { 2 - 5 } & \multicolumn{1}{c}{$\mathrm{A}$} & $\mathrm{B}$ & $\mathrm{C}$ & $\mathrm{D}$ \\
\hline Bahan kering & $33,72^{\mathrm{a}}$ & $48,09^{\mathrm{b}}$ & $50,36^{\mathrm{c}}$ & $46,36^{\mathrm{b}}$ \\
Bahan organik & $38,37^{\mathrm{a}}$ & $51,51^{\mathrm{b}}$ & $52,93^{\mathrm{c}}$ & $50,76^{\mathrm{b}}$ \\
NDF & $28,80^{\mathrm{a}}$ & $34,82^{\mathrm{b}}$ & $39,50^{\mathrm{c}}$ & $30,56^{\mathrm{b}}$ \\
ADF & $20,90^{\mathrm{a}}$ & $29,73^{\mathrm{b}}$ & $34,88^{\mathrm{c}}$ & $26,00^{\mathrm{b}}$ \\
Sellulosa & $15,62^{\mathrm{a}}$ & $24,1^{\mathrm{b}}$ & $28,25^{\mathrm{d}}$ & $20,00^{\mathrm{c}}$ \\
Hemiselulosa & $23,25^{\mathrm{a}}$ & $30,5^{\mathrm{b}}$ & $36,54^{\mathrm{c}}$ & $28,33^{\mathrm{b}}$ \\
\hline Keterangan : & $\mathrm{A}=$ TKKS tanpa fermentasi & \\
& $\mathrm{B}=$ TKKS yang difermentasi selama 1 minggu \\
& $\mathrm{C}=$ TKKS yang difermentasi selama 2 minggu \\
& $\mathrm{D}=$ TKKS yang difermentasi selama 3 minggu \\
& $\begin{array}{l}\text { Superskrip dengan huruf yang berbeda menunjukkan perbedaan yang sangat } \\
\text { nyata (P< 0,01) }\end{array}$
\end{tabular}

Tabel 3. Rataan $\mathrm{pH}, \mathrm{Kadar}$ NH3 dan VFA Cairan Rumen dari TKKS Percobaan

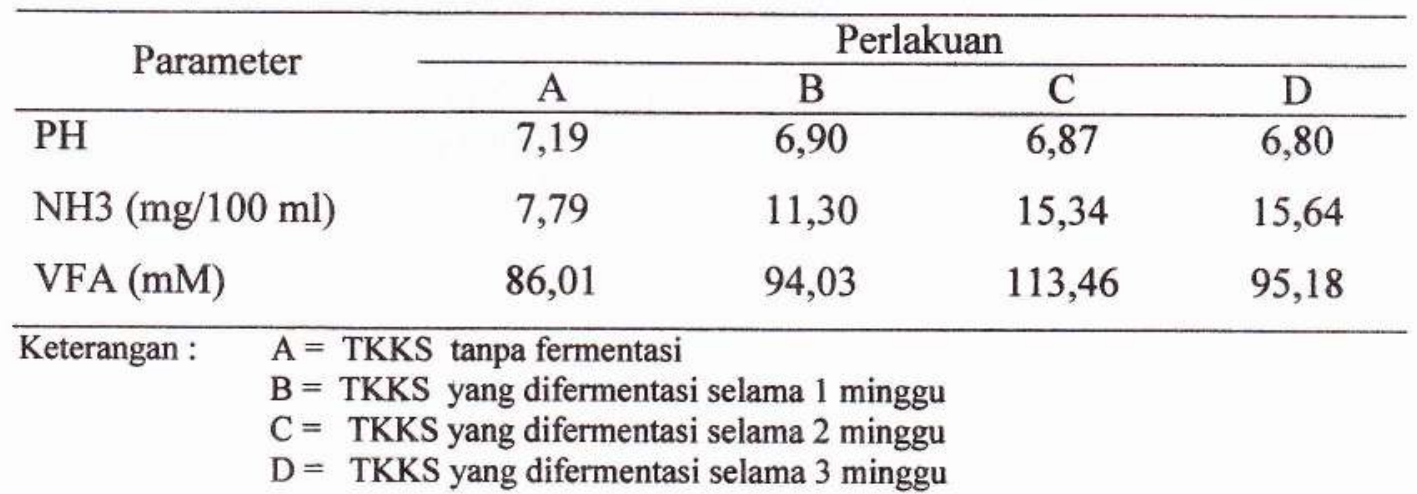


Dari Tabel 3 juga terlihat bahwa kadar $\mathrm{NH} 3$ cenderung meningkat dengan meningkatnya lama fermentasi. Hal ini disebabkan semakin lama fermentasi semakin banyak mikroba yang tumbuh dan karena sebagian besar tubuh mikroba adalah protein maka mikroba itu menyumbang protein pada tandan kosong kelapa sawit sehingga NH3 yang dihasilkan menjadi meningkat. Produksi NH3 yang didapatkan pada penelitian ini berkisar antara 7,79 - 15,64 mg/100 ml cairan rumen. Kadar NH3 ini sudah cukup untuk memenuhi kebutuhan mikroba rumen dimana kebutuhan minimum mikroba rumen terhadap $\mathrm{NH} 3$ adalah $5 \mathrm{mg} / 100 \mathrm{ml}$ cairan rumen (Satter and Slyter,1974).

Kadar VFA walaupun menunjukkan perbedaan yang tidak nyata antar perlakuan, namun dari Tabel 3 terlihat bahwa pola produksi VFA sama dengan pola kecernaan zat-zat makanan. VFA tertinggi didapatkan pada perlakuan $\mathrm{C}$, dimana kecernaan zat-zat makanan juga tertinggi pada perlakuan C. Hal ini disebabkan produk metabolisme zat makanan terutama fraksi serat yang merupakan karbohidrat adalah VFA. Meningkatnya produksi VFA pada TKKS yang difermentasi sampai 2 minggu menunjukkan bahwa TKKS ini lebih fermentabel dalam rumen.

\section{Kesimpulan}

Dari hasil penelitian dapat disimpulkan bahwa tandan kosong kelapa sawit dapat ditingkatkan kecernaan dan fermentabilitasnya melalui fermentasi menggunakan mikroba tanah selama 2 minggu.

\section{Daftar Pustaka}

Alexander, M. 1977. Introduction to Soil Microbiology. 2 nd ed.
John Willey and Sons, Inc., New York, Chichester, Brisbane, Toronto.

Dharmaputra, O.S., A.W. Gunawan dan Nampiah. 1989. Penuntun Praktikum Mikologi Dasar. Dirjen Pendidikan Tinggi, PAU, limu Hayat, IPB, Bogor.

Ibrahim, M.N.M. and G.R. Pearce. 1980. Effect of White Rot Fungi on the composition and in vitro digestibility of crop by products. Agric. Wastes. 2: 199-205

Landecker, E.M. 1972. Fundamental of the Fungi. Prentice Hall Inc., New York University. New York.

LimLim, K.W. and Ladisch, M.R. 1985. Effect of pretreatment and fermentation on pore size in cellulose materials. Biotechnol. Bioeng, 27. 14271433

Mardiati, Zain, T. Sutardi, D. Sastradipradja, Suryahadi, dan N. Ramli 2000. Pemanfaatan Serat Sawit Sebagai Pakan Pengganti Rumput dalam Ransum Ternak Domba. Proseding Seminar Nasional Pengembangan Ternak Sapi dan Kerbau, Padang, 11 Oktober 2000.

Mardiati Zain, N. Jamarun dan Y. Rahman, 2001. Pemanfaatan Tandan Kosong Sawit Sebagai Pakan Ternak. Jurnal Akademika Volume 5 No. 1

Parkinson, D., T.R.G. Gray and S.T. Williams. 1971. Methods for 
studying the ecology of Soil Microorganism. International Biological Programme. No. 19. Blackwell Scientific Publications. Oxford and Edinburgh.

Saddler, J.N. Brownell, H.H. Clemont, L.P. and Levitin, N. 1982. Enzymatic hydrolysis of cellulose and various pretreat wood fractions. Biotechnol. Bioeng. 24, 1389-1402
Steel, R.G.D. and J.H. Torrie. 1980. Principles and Procedure of Statistics. McGraw-Hill Book Co. Inc. New York.

Sutardi, 1980. Landasan Ilmu Nutrisi. Jilid 1. Departemen Ilmu Makanan Ternak, Fakultas Peternakan, IPB, Bogor.

Yunus, A. 1991. Mengolah Jerami Menjadi Pakan Bermutu. Swadaya Peternakan. Jakarta. Agustus 1991, 75: 24-26

\begin{abstract}
Alamat Korespondensi: Dr. Ir. Mardiati Zain, MS Jurusan Nutrisi dan Makanan Ternak Fakultas Peternakan Universitas Andalas Kampus Limau Manis Padang
\end{abstract}

Artikel diterima 6 September 2006, disetujui 17 Oktober 2006 